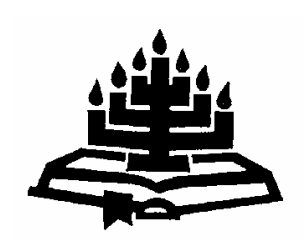

\title{
Watter sake hoort by meerdere vergaderings?
}

\author{
P.J. Strauss \\ Departement Ekklesiologie \\ Universiteit van die Vrystaat \\ BLOEMFONTEIN \\ E-pos: straussp.hum@mail.uovs.ac.za
}

\begin{abstract}
:
Which issues should be dealt with by major assemblies?

It seems as if the reformed churches, in their distinction between minor and major assemblies, will always have to keep a balance between maintaining the right of the congregation as a fully-fledged church and the necessity or right of the church as a denomination. In order to achieve this, Article 30 of the Church Order of Dordt 1619 was the temporary end of a development in that church order tradition which carries the name of Dordt. Freely translated, Article 30 states:
\end{abstract}

\section{Major assemblies shall deal only with those matters which concern its churches in common or which could not be finished in the minor assemblies.}

With minor changes made by some churches, this formulation has withstood the test of time up till today. It can, however, also stand up to a test based on a sound reformed ecclesiology. Such an ecclesiology accepts in principle that the congregation is a fully-fledged church, but, at the same time, also sees the need for a meaningful bond between congregations (the denomination) as a visible sign of the unity of the church. In this bond major assemblies - like consistories - could also only act under an authority entrusted to them by Christ.

\section{Opsomming:}

Watter sake hoort by meerdere vergaderings?

Dit wil voorkom asof die gereformeerde kerke met hulle onderskeid tussen mindere en meerdere vergaderings, altyd 'n balans sal moet vind tussen die reg van die gemeente as volledig kerk en die noodsaak of reg van die kerkverband. In 
hierdie opsig was artikel 30 van die bekende Dordtse Kerkorde van 1619 'n tydelike kulminasiepunt in die ontwikkeling binne hierdie kerkordelike tradisie. Vry vertaal lui artikel 30 so:

Op meerdere vergaderings moet alleen sake behandel word wat die gemeentes gemeenskaplik raak of wat nie in mindere vergaderings afgehandel kan word nie.

Hierdie bepaling het sedertdien geringe wysigings in gereformeerde kerke in hierdie tradisie ondergaan, maar het in sy kern, tot vandag toe, die toets van die tyd deurstaan. Dit slaag egter ook die toets van 'n begronde gereformeerde ekklesiologie. So 'n ekklesiologie aanvaar die gemeente as volledig kerk, maar maak ook ruimte vir 'n sinvolle verband tussen gemeentes as uitdrukking van die sigbare eenheid van die kerk. In hierdie verband tree meerdere vergaderings - soos kerkrade - ook alleen op met die bevoegdheid of gesag wat aan hulle deur Christus verleen is.

\section{Inleiding}

In gereformeerde kringe bly die vraag na die verhouding tussen die gemeente, soos verteenwoordig deur die kerkraad, en die kerkverband, soos onder meer uitgedruk in meerdere vergaderings soos klassisse en sinodes, problematies en daarom aktueel. Hierdie aktualiteit word op die spits gedryf deur die oortuiging by baie gereformeerdes dat die gemeente volledig en selfstandig kerk is, maar dat een of ander vorm van kerkverband, waarin die verskillende gemeentes gebind word deur gesamentlike besluitneming en optrede, ook 'n noodsaaklikheid is, naamlik dat die gemeente volledig kerk is, maar nie die hele kerk nie (Heyns, 1977:170). Daar bestaan by baie in hierdie kringe ook die kommer dat die verwerping van 'n kollegialistiese en Roomse superkerkidee, waarin gemeentes tot gesiglose takke van die één groot verband verword, nie tot sy teenpool, 'n verdelende independentisme, moet lei nie (Visser, 1999:129). Dit is byna asof gereformeerdes op hierdie punt nie wegkom van 'n voortdurende delikate balansering tussen die reg van die gemeente en die reg van die kerkverband nie.

Dat hierdie probleem nie denkbeeldig is nie, is ook in gereformeerde kerke in Suid-Afrika sigbaar. In 2002 besluit die Algemene Sinode van die Nederduitse Gereformeerde Kerk om 'n studie te laat doen oor die werksterreine van onderskeidelik die kerkraad, ring, sinode en algemene sinode (NGK, 2002:557-558). 'n Groeiende independentisme, gebou op 'n gees van indiwidualisme in hierdie en 
ander gereformeerde kerke in Suid-Afrika is tans sigbaar. Hierdie independentisme druk hom onder meer uit in die liturgie en die gebruik van liturgiese formuliere, lidmaatskap van of selfs net 'n assosiasie met die gemeente van eie keuse en die houding teenoor die besluite van meerdere vergaderings (Strauss, 2001:398-399).

Om die prinsipiële verhouding tussen gemeente en kerkverband, of respektiewelik, kerkraad en meerdere vergaderings, bloot te lê, gebruik verskillende gereformeerdes verskillende omskrywings.

Die bekende gereformeerde kerkregtelike, H. Bouwman (1985:33), soek byvoorbeeld na 'n verhouding waarin die vryheid en selfstandigheid van die gemeente verseker én die bevoegdheidskringe van meerdere vergaderings afgebaken word. Van Dellen en Monsma (1967:120), wat sterk klem op die gemeente lê, streef na 'n beperking van die gesag van meerdere vergaderings, sodat die selfstandigheid, gesag en integriteit van die gemeentes gehandhaaf word. Spoelstra (1989:179) sien die ideaal in die gemeentes as selfstandige kerke wat vrywillig met ander kombineer, om saam te doen dit wat tot die "eenheid, goeie orde en beswil" van elkeen strek - 'n ooreenkoms dus waarin elkeen se "soewereiniteit" beskerm word, maar hulle ook in belang van mekaar gesamentlik optree.1 Van der Linde (1983:124) oordeel dat die ideale verhouding voorafgegaan moet word deur die erkenning dat die "plaaslike kerk (tegelyk) selfstandig en afhanklik is." Met ietwat van 'n ander klem bepleit Pont (1981:221) die erkenning van die volledige kerkwees van sowel die gemeente as die kerverband.

Wat reeds by hierdie min of meer erkende gereformeerde kerkregtelikes duidelik is, is dat alles nie so maklik af te baken of te onderskei is nie. Dit gaan hier meer oor beginsels wat in die kerkordelike praktyk van elke kerkverband of -gemeenskap konkreet gestalte moet kry. Van Dellen en Monsma (1967:120) bevestig hierdie oordeel, deur die saak waarom dit hier gaan as 'n

1 Spoelstra se toekenning van "soewereiniteit" aan die gemeentes is in die lig van die Skrif problematies. In die Bybelse sin van die woord beskik net God en daarom ook Christus as die Hoof van sy kerk, oor soewereiniteit. Volgens Spoelstra sluit hierdie opvatting aan by die sestiende-eeuse feodale stelsel met sy pluralisme, waarin die soewereiniteit, vryheid en verantwoordelikheid van korporasies, genootskappe, munisipaliteite en provinsies teenoor die sentrale owerhede erken is. Sy standpunt huiwer egter op die rand van 'n onkritiese vermenging van die twee sake. Kyk ook Bouwman (1985:15) se skerp afwysing van die "absolute souvereiniteit der afzonderlijke kerken". Volgens hom is dit altoos deur gereformeerdes bestry. 
fundamentele aangeleentheid vir gereformeerde kerkregering te beskryf.

Met die uitsondering van Pont, is daar by al dié betrokke skrywers 'n beweging wat by die gemeente begin en die selfstandigheid en vryheid daarvan vooropstel. Die verband staan by hulle in diens van die gemeentes en daarom moet die vergaderings van die verband sover moontlik beperk word om die vryheid en selfstandigheid van die gemeentes, sover moontlik, ongeskonde te laat. Meerdere vergaderings pak net daardie sake aan wat die kerkraad as gesagvolle vergadering in die gemeente nie kan hanteer of oplos nie. Die klem van kerkwees val op die gemeente, of anders gestel, kerkwees setel in sy kern in die gemeente.

Op die oog af wil dit voorkom asof hierdie skrywers steun vind in die ou bepaling in die Dordtse kerkordelike tradisie van die sestiende en sewentiende eeu dat meerdere vergaderings slegs twee soorte sake hanteer: daardie sake wat nie op mindere vergaderings afgehandel kon word nie én daardie sake wat die gemeentes met mekaar in gemeen het. Die bekende Dordtse Kerkorde van 1619 (DKO) stel dit in sy artikel 30 (voortaan gebruik as DKO-30) so:

In meerdere vergaderinge sal men niet handelen, dan t'gene in mindere niet heeft afgehandelt konnen worden, ofte dat dat tot den Kercken der meerder vergaderinghe int ghemyen behoort (Biesterveld \& Kuyper, 1905:234).

Verskillende vrae ontstaan: Is die opgesomde houding van hierdie outeurs die korrekte interpretasie van hierdie ou bepaling. Hoe raak hierdie siening die gesag van sowel die kerkraad as meerdere vergaderings? As dit aanvaar word dat die gemeente volledig kerk is, hoe belangrik is hierdie bepaling om dié volledige kerkwees te beskerm? Wat is dan 'n werkbare kerkordelike oplossing vir 'n gesonde verhouding tussen gemeente en kerkverband?

'n Laaste vraag is natuurlik of hierdie bepaling sedertdien wysigings ondergaan het en waarom dit gebeur het.

\section{Die Dordtse kerkordelike tradisie: bepalings}

Die eerste spore van DKO-30 vind ons by die artikels van die Nasionale Sinode van Emden in 1571. Dit is bekend dat die DKO 'n voorlopige eindpunt vorm van die kerkordelike ontwikkeling wat die "Vaderlandse" Gereformeerde Kerk in Nederland in die sestiende en sewentiende eeu deurmaak. Die DKO was eintlik niks meer nie as die hersiening van 'n kerkorde waarvan die eerste spitwerk reeds by 
die Konvent van Wezel in 1568 en by die Sinode van Emden in 1571 gedoen is - 'n hersiening van die kerkorde van die Nasionale Sinode van Den Haag (1586), terwyl Den Haag op sy beurt vir Middelburg (1581), Middelburg vir Dordrecht (1578) en Dordrecht vir Emden (1571) hersien het (Rutgers, 1971). Na 1619 sou die Nasionale Sinode eers weer in die negentiende eeu byeenkom én hom dan op 'n radikaal anderse kerkordelike weg bevind (vgl. Pont, 1991:1, 10 e.v.).

Ten opsigte van die klassis verklaar Emden dat dit nie sake moet hanteer wat in die kerkraad afgehandel kan word nie. Op sy beurt moet die provinsiale sinode nie sake hanteer wat in die kerkraad of klassis afgehandel kon word nie. Die nasionale of algemene sinode moet hom bepaal by dit wat kerkordelik vir hom voorgeskryf is, naamlik sake oor die leer en die kerkorde en ook sake wat nie in die provinsiale sinodes afgehandel kon word nie (Rutgers, 1889:107,109,117-118). ${ }^{2}$ In 1578 vat Dortrecht hierdie artikels van Emden in een artikel saam met die volgende woorde:

Men sal gheene saken tot grooter versamelinghen brengen dan die in den minderen niet en hebben konnen afghehandelt worden, ofte die de Kercken in het ghemeyne aengaen (Rutgers, 1889:240).

Middelburg herformuleer dieselfde saak in 1581 - ' $n$ formulering wat ook in DKO-30 opgeneem word en wat feitlik ongewysigd wye navolging in ander gereformeerde kerkordes vind (Bos, 1950:107; Jansen, 1952:142; Van Dellen \& Monsma, 1967:117). Dit bring mee dat hierdie formulering mettertyd 'n klassieke uitdrukking in die gereformeerde kerkreg word (vgl. Bouwman, 1985:34; Rutgers, 1889: 385; Pont, 1981:179). ${ }^{3}$

Die vraag is: Wat word met hierdie bewoording in die Nederlandse gereformeerde kerkordelike tradisie van destyds bedoel en hoe skakel dit in by die beskouing van destyds oor kerkverband? Belangrike rigtingwysers in dié verband is natuurlik die teks van hierdie kerkordes self, maar ook die ekklesiologiese (teologiese) konteks waarin dit geformuleer is.

2 Rutgers gee hier die Latynse Acta plus 'n Nederlandse vertaling van die Sinode van Emden van 1571 weer.

3 De Gier (1989:164) gee 'n meer moderne Nederlandse vertaling hiervan: "in meerdere vergaderingen zal men niet handelen, dan hetgeen dat in mindere niet heeft afgehandeld kunnen worden, of dat tot kerken der meerdere vergadering in het gemeen behoort". 


\section{Die Dordtse kerkordelike tradisie: interpretasie}

Dit is duidelik dat die woordjie kerk of kerke in hierdie kerkordelike tradisie vir gemeentes gebruik word en dat die meerdere vergaderings dui op vergaderings van hierdie kerke of gemeentes. Daarom beteken die uitdrukking "meerdere" hier nie hoër of belangriker of beklee met groter gesag nie. Dit is bloot 'n aanduiding daarvan dat meer gemeentes saam vergader. Die sprekende eenvoud van Dordt 1578 se formulering bevestig dit: dit is "grooter versamelinghen" van "Kerkcken". Meer of meerdere in die Dordtse tradisie beteken eenvoudig meer as een kerk of gemeente (vgl. Van Dellen \& Monsma, 1967:120-121; Bouwman, 1985:17). Meerdere vergaderings as ' $\mathrm{n}$ uitdrukking van kerkverband is in hierdie tradisie per definisie vergaderings van die gemeentes of kerke van hierdie verband. Omdat alle gemeente- of kerkraadslede om verskeie redes nie almal op hierdie vergaderings kan sitting neem nie, is meerdere vergaderings vergaderings van gemeentes deur middel van hulle afgevaardigdes (Du Plooy, 1979:117; Strauss, 1999:41 e.v.).4

Dat die gemeente hier kerk genoem word, is hoogs waarskynlik ook 'n aanduiding daarvan dat dit in die Dordtse tradisie as volledig kerk of ecclesia completa beskou is. Hoewel hierdie uitdrukking nie in die kerkordes van die sestiende en sewentiende eeu voorkom nie en dit as 'n tegniese term later ontwikkel, is die saak waarom dit hier gaan reeds in die sestiende eeu by die Nederlandse gereformeerdes aanwesig. Rutgers toon oortuigend aan uit korrespondensie van betrokkenes by die Sinode van Emden in 1571, dat hulle die vestiging van 'n sinodale verband tussen die gereformeerde "hollandse" gemeentes of kerke binne en buite Nederland noodsaaklik geag het vir die eer van God en die opbou van sy "lieue Gemeijnte". Die voorgestelde "versameling van kerke" in 'n algemene sinode sou groot nut vir die kerke (gemeentes) inhou en hulle eenheid bevorder (Rutgers, 1971:16). Kerkverband as 'n verband van gemeentes waarin dit gaan om die eenheid en "profijt der Kercken" kom ook in die laaste artikel van Emden voor. Die profyt van die kerke of gemeentes moet ook die doel wees vir die vasstelling van 'n kerkorde vir die gemeentes - én hulle verband deur die sinode, as die wydste gemeenskaplike vergadering van hierdie gemeentes. Met die uitsondering van Dordt 1578, word die

$4 \quad$ Voetius en Bouwman maak ook 'n saak daarvoor uit dat meerdere vergaderinge nie noodwendig uit gemeentelike ampsdraers hoef te bestaan nie, sodat die amptelikheid van hierdie vergaderings nie aan die feit dat hulle lede ampte in die gemeentes beklee, gekoppel moet word nie. Albei beskou dit egter ook as 'n uitsondering op die reël (vgl. Voetius, s.a:194, 199 en Bouwman, 1985:135-136). 
"profyt-artikel" as laaste artikel in elke kerkorde in hierdie tradisie tot 1619 gehandhaaf (Rutgers, 1971:13; Pont, 1981:186).

Bouwman en andere word dus vanuit hierdie geskiedenis ondersteun in hulle tese dat kerkverband die gemeentes moet dien. Die sake wat hanteer word by meerdere vergaderings, as die vergaderings van die verband, moet hierdie ideaal versterk. Dit is ook duidelik dat die klem hier op die gemeentes as kerke val en dat hulle beslis nie in die kerkverband oplos nie. Dit wat Bouwman en andere die selfstandigheid en integriteit van die "kerke" noem, word erken en gerespekteer. 5 Wat in die praktyk die eenheid en gemeenskaplike sake van die gemeentes is waarop meerdere vergaderings moet konsentreer, word nie in DKO-30 in besonderhede uitgestippel nie. Dit moet uit 'n logiese oogpunt en die konteks van die DKO self egter duidelik wees dat dit nie 'n blote herhaling van gemeente- of kerkraadsake kan wees nie. DKO-30 bepaal immers dat meerdere vergaderings nie sake hanteer wat mindere vergaderings kan afhandel nie.

Hoe het die kerkordes in die Dordtse tradisie, van 1571 tot 1619, hierdie beginsel in die res van hulle eie bepalings tot gelding probeer bring?

\section{Die Dordtse kerkordelike tradisie: eie toepassing}

Vir Emden is die klassis 'n vergadering wat die gemeentes help en bystaan in hulle kerkwees (Pont, 1981:99). Klassisse moet op die sake van die naburige gemeentes wat daarin saamtrek, konsentreer en die frekwensie van hulle vergaderings moet ondermeer deur die "nootdruft" (nood - PJS) van hierdie gemeentes bepaal word. Klassisse moet dus meer gereeld as die sinodes byeenkom (Rutgers, 1889:58, 107). Hierdie agenda vir die klassis word deur die daaropvolgende sinodes in dié tradisie gehandhaaf. In wat as die kerkvisitasietaak van die klassis beskryf word, gee Dordt 1578 én 1619, Middelburg 1581 en Den Haag 1586 ook spesifieke opdragte en vrae wat die klassis hiervoor moet gebruik (vgl. Pont, 1981:134-135, 180-181).

Prinsipieel beskou gaan dit hier oor 'n onderlinge herderlike versorgingstaak teenoor mekaar, wat die gemeentes in 'n bepaalde omgewing gesamentlik aanvaar. Dit is 'n taak wat nie deur die kerkraad oorgeneem of afgehandel kan word nie, en wat as opdrag hulle almal raak. Dit voldoen en gee dus uitvoering aan albei 
vereistes van die klassieke bepaling wat uiteindelik deel van DKO30 word.

Wat die streeks-, partikuliere of provinsiale sinodes - in onderskeiding van die algemene of nasionale sinode - en die klassis hanteer, is egter nie so duidelik nie. Die onduidelikheid blyk uit 'n deurskou van die kerkordes vanaf Emden in 1571 tot by Dordrecht in 1619. In die lig van die tekste van hierdie kerkordes en die kommentaar van etlike skrywers daarop, wil dit voorkom asof partikuliere sinodes die volgende moes hanteer: moeilike sake wat nie deur van die klassisse in sy gebied afgehandel kon word nie ("swarigheidsdeputate" moes hiermee help), adviese aan klassisse, die hantering van appèlle by die eksaminering, ontslag, afsetting, bedanking en emeritering van predikante (nog 'n taak van die klassis) en 'n vaag omskrewe rubriek wat as "gemeenskaplike partikuliere vraagstukke in die resort van die sinode" beskryf is. Opgesom kom dit moontlik daarop neer dat hierdie sinodes partikuliere sake sowel as sake wat verband hou met die leer en orde van die kerk én wat kerkrade of klassisse nie kon afhandel nie, moes behartig. In hierdie opsig het dit 'n belangrike eenheidsvormende funksie gehad (vgl. Biesterveld \& Kuyper, 1905:107-108, 147-151, 199-204, 234-239; Nauta, 1971:211-212; Plomp, 1971:92-93; Pont, 1981:235; Harmannij, 1990:76). Dit wil dus lyk asof die twee eise van die stelreël in DKO-30, naamlik dat hierdie sinodes alleen daardie sake hanteer wat nie op mindere vergaderinge afgehandel kon word nie en gemeenskaplike sake wat nêrens anders tuishoort nie, hiermee nagekom is.

Dieselfde kerkordes laat na om die take van die algemene sinode te omskryf. By die Konvent van Wezel in 1568 word egter 'n algemene sinode in die vooruitsig gestel wat hom toespits op sake ten bate van die gemeenskaplike inrigting van "der kerken" en die onderhouding van "een zo voortreffelijk mogelijke orde". Dit gaan dus oor sake wat al die kerke of gemeentes in hulle breedste verband raak en die orde van die kerk (Biesterveld \& Kuyper, 1905:2-3). Op sy beurt oordeel Emden dat 'n algemene sinode hom moet bepaal by sake oor die leer en kerkorde en dit wat nie in die partikuliere sinodes afgehandel kon word nie (Rutgers, 1889:107, 109, 117-118). Die Dordtse Sinode (1618-1619) het die kerkorde vasgestel, wat op sigself meebring dat die algemene sinode die grondlyne vasstel vir die ampte, vergaderings en die arbeid waaronder erediens en tug - van die kerk (vgl. DKO; Biesterveld \& Kuyper, 1905:225-250). Dit is ook wyd bekend dat die Dordtse Sinode van 1618-1919 die belydenis vasgestel het (Pont, 
1981:168). ${ }^{6}$ Ook hier is hoofsaaklik daardie sake te berde gebring wat die kerke of gemeentes in hulle breedste sin in gemeen gehad het en wat nie deur ' $n$ mindere vergadering afgehandel kon word nie.

In sy geheel gesien wil dit voorkom asof die Nederlandse Gereformeerde Kerk van die sestiende en sewentiende eeu - ten minste in sy kerkordes en vergaderings - streng wou bly by hierdie bepaling wat uiteindelik deel van DKO-30 sou word. Die selfstandige kerkwees van die gemeentes is met hierdie stelreël erken, sonder om die deur vir independentisme by gemeentes oop te maak. Inteendeel, die noodsaak van die kerkverband - hier 'n sinodale verband - soos gebou op die bestaande belydeniseenheid tussen hierdie gemeentes, is onverkort gehandhaaf (Engelsma, 1996:58). Die selfstandigheid is immers beskou as ' $n$ middel tot nut en opbou van die gemeentes en boonop tot hulle oorlewing in die sestiende eeu in 'n omgewing wat nie altyd gunstig vir gereformeerdes was nie (Van 't Spijker, 1971:50 e.v.).

Sekere omstrede kwessies in die negentiende en twintigste eeu in die Nederlandse kerkordelike tradisie, was nog nie in fokus nie. In hierdie verband kan verwys word na dinge soos die aard van die gesag van meerdere vergaderings; of die uitdrukking kerk of kerke as naam vir 'n spesifieke kerkverband as 'n verband van gemeentes (of kerke) gebruik moet word; of die selfstandigheid van die gemeente aan hom 'n ratifikasiereg ten opsigte van die besluite van meerdere vergaderings gee; en of gemeentes vrywillig of

Pont (1981:236) betoog sonder behoorlike steun uit die tekste van die kerkordes van 1568-1619, dat die algemene sinode vanweë sy bepaalde werksterrein van "groot belang" vir "die kerk" was. Hierdie arbeidsveld sou dan wees die vasstelling van die belydenis en kerkorde, die handhawing van dissipline, die inrigting van die erediens en die tref van maatreëls wat die algemene welstand van "die kerk" bevorder. Veral sy verwysing na dissipline en die algemene welstand neig na 'n grensoorskryding met partikuliere sinodes. Vergelyk Van Wyk (1981:82) wat Pont in hierdie opsig navolg. Die uitdrukking "groot belang" wat Pont vir die algemene sinode reserveer, dui op 'n klemverskil met andere, soos Bouwman, as dit kom by die waardering van die rol van hierdie vergadering in die kerk in verhouding met die kerkraad. Direk teenoor Pont staan Spoelstra (1989:185) wat die klassis die belangrikste meerdere vergadering noem, omdat dit van almal die naaste aan die "selfstandige kerkraad" is. Die begrippe groot belang en belangrikste is hier egter irrelevant, omdat elke vergadering sy plek het en belangrik is, met geen hiërargie of rangorde nie. So iets is vreemd aan die gereformeerde kerkregtelike tradisie en kom ook nie in Dordtse tradisie voor nie. 'n Gereformeerde verstaan van kerkvergaderings gaan uit van 'n gelyke, plat struktuur wat verder uitwaaier soos wat meer gemeentes by 'n volgende vergadering met sy eie agenda betrek word. Die vergaderings is gelyk, maar verskil in opdrag (vgl. Strauss, 1997:92). 
gehoorsaam-vrywillig tot kerkverband toetree. In vergelyking met die negentiende en twintigste eeu het die sestiende- en sewentiendeeeuse Nederlandse gereformeerdes hierin dus 'n redelik ongekompliseerde karakter vertoon.

Die vraag ontstaan verder of die formulering van hierdie stelreël in DKO-30 sedertdien wysigings ondergaan het en indien wel, wat die effek daarvan is.

Moderne gereformeerde kerkordes toon geringe wysigings van die formulering van DKO-30, naamlik dat meerdere vergaderings alleen sake hanteer wat nie deur mindere vergaderings afgehandel kon word nie, of wat die kerke wat in hierdie vergaderings verteenwoordig is, in gemeen het (vgl. Engelhard \& Hofman, 2001:166-167; Visser, 1999:125; NGKA, s.a.:4). Die mees beduidende wysigings kom voor by die "Samen-op-weg"-kerk, die Protestantse Kerk in Nederland (PKN) en twee Suid-Afrikaanse kerke, naamlik die Gereformeerde Kerke in Suid-Afrika (GKSA) en die Nederduitse Gereformeerde Kerk (NGK).

In hoofstuk 6, artikel 11 van sy Kerkorde bepaal die PKN dat meerdere vergaderinge alleen sake kan behandel wat volgens die "orde van de kerk" hulle werk is, of sake wat nie op mindere vergaderinge afgehandel kon word nie (PKN, s.a.:6). DKO-30 se sake wat die kerke, soos verteenwoordig in die meerdere vergadering, met mekaar in gemeen het, word by die twee SuidAfrikaanse kerke vervang met sake wat by so 'n vergadering "tuishoort". Die GKSA, wat steeds die DKO as basis gebruik, stel dit in sy Kerkorde in artikel 30 (Visser, 1999:125). In die Kerkorde van die NGK is dit artikel 22.1 (NGK, 2003:11).

Die kwessie van "tuishoort" kan hier vanuit twee hoeke verstaan word. Die een is dat dit deur die begrip wat die samestellende kerke in gemeen het bepaal word. So gesien is dit in werklikheid nie 'n wysiging nie en funksioneer dit steeds vanuit dieselfde breë beginsel as DKO-30. Dit bly dus 'n opdrag wat sowel die kerkorde as die funksionering van meerdere vergaderings moet bepaal. Die ander uitgangspunt is dat hierdie tuishoort, soos in die geval van die NGK, bloot aan die hand van bepalings in die kerkorde, wat die take van elke meerdere vergadering omskryf, vasgestel word. Dan verskuif die klem van 'n genormeerde (die ius constituendum) na 'n gepositiveerde kerkreg (die ius constitutum) as vertrekpunt en beperk dit die reformatoriese potensiaal wat daar moontlik in hierdie stelreël of die breë beginsel van sake wat die gemeentes in gemeen het, opgesluit lê. Die PKN se gebruik van die orde van die kerk in 
plaas van die beginsel, neig ook na 'n negering van die ius constituendum - 'n formulering ontleen aan die Kerkorde van die Nederlandse Hervormde Kerk, een van die kerke wat in die PKN verenig is (Van den Heuvel, 1991:103).

DKO-30 het die "toets van die tyd" dus min of meer deurstaan. Kan dit egter ook 'n gereformeerd-kerkregtelike beoordeling vanuit die prinsipiële aard van kerkverband deurstaan?

\section{DKO-30: prinsipieel getoets}

Daar heers breë eenstemmigheid onder gereformeerdes dat kerkverband 'n verband van gemeentes is - of dit 'n nouer sinodale of 'n losser federale verband is. Kerkverband is, prinsipieel gesien, 'n verband van gemeentes as volledige kerke of ecclesiae completae. Dat die gemeente volledig kerk is, beteken egter nie dat hy volmaak kerk of die hele kerk is nie. Dit beteken eenvoudig net dat die merktekens of kenmerke van die kerk (die onderskeidende eienskappe wat die kerk, as kring van Christengelowiges, kérk maak) alleen in die gemeente aangetref kan word. Vir die "ware kerk" is hierdie merktekens die suiwere bediening van die Woord en die sakramente en die handhawing van die kerklike tug (vgl. Du Plooy, 1979:80 e.v.; Spoelstra, 1989:177). As begronding hiervoor dien die Skriflyne, soos saamgetrek in artikel 29 van die Nederlandse Geloofsbelydenis. Histories gaan hierdie benadering egter terug op Calvyn (Strauss, 1999:42 e.v.).

Die gelowige is dus nie 'n lidmaat van die kerkverband of die kerk in die breë nie, maar van die gemeente. Dit is in die gemeente waar hy sy kerklike voorregte uitoefen of sy aandeel aan die bediening van die kerk het (Sadler, 1991:65 e.v.). Die gemeente bly kerk - volledig kerk - selfs al sou daar net een gemeente op aarde oorbly (Bavinck, 1967:356).

Juis omdat die gemeente na sy aard kerk is, en omdat hy deel is van die een heilige algemene Christelike kerk wat ons op grond van die Skrif in die Apostolicum bely, tree hy gehoorsaam en gewillig toe tot kerkverband saam met ander gemeentes, wat dieselfde belydenis en hoofsake van kerkinrigting as hy huldig en dit in die praktyk handhaaf (Bouwman, 1985:16-17) ${ }^{7}$. Al sou die kerkraad alle

$7 \quad$ As dit kom by toetrede tot kerkverband, gebruik Rutgers (1971:13-16) en ander in die sogenaamde Doleansiekerkreg liewer die woordjie "vrywillig". Daarmee wil hulle die gesag en selfstandigheid van die gemeente as kerk beskerm, maar trap hulle in die slaggat om die Goddelike eis tot eenheid, soos vergestalt in 
kerklike sake kon hanteer, dryf die diepe oortuiging van die eenheid en algemeenheid van die kerk - van die noodsaak dat die gelowiges as die universele liggaam van Christus hulle gawes tot nut en saligheid van mekaar aanwend $\mathbf{8}$ - hom daartoe om met gemeentes wat hierdie kernwaarhede met hom deel, kerkverband te soek en gemeenskaplike sake in die vergaderings van hierdie verband af te handel. Daarom is meerdere vergaderings vergaderings van gemeentes of kerke deur middel van hulle afgevaardigdes.

Gemeentes boet hiermee niks van hulle volledige kerkwees in nie. Die kerkraad aan wie die toesig en regering van die gemeente toevertrou is, kan steeds alle kerklike sake hanteer, maar kom by toetrede tot die verband ooreen dat sommige sake alleen deur die meerdere vergaderings afgehandel kan word 9 . Wie watter sake afhandel, word op basis van die kerkorde vasgestel, wat op sy beurt met die aard van kerkverband en meerdere vergaderings rekening moet hou. Gebeur dit so en bou hierdie besluite van meerdere vergaderings op die Woord, is dit net so bindend op die gemeentes as die besluite van kerkrade. Gemeentes tree gewillig toe tot die verband waarin die belydenis, as akkoord van kerklike gemeenskap, die mees fundamentele uitdrukking van hulle eenheid is. Die kerkorde waarop hulle besluit gee die praktiese lyne vir die funksionering van die gemeentes binne die verband. Daarom aanvaar die gemeentes die bindende krag van die besluite van meerdere vergaderings (vgl. Bouwman, 1985:2 e.v.).

In die lig hiervan is DKO-30 'n wyse en prinsipieel gefundeerde maatreël om sowel die kerkraad as meerdere vergaderings tot hulle reg te laat kom. Daarom het dit tot nou toe in talle kerkordes oorleef. Wat kerkrade of mindere vergaderings kan afhandel, moet gedoen word. Sodoende word enersyds die volledige kerkwees van gemeentes beskerm en andersyds gewaak teen die sentralisering van kerkwees of kerklike besluite in 'n kleiner groep, weg van die gemeente waar die merktekens soos beskrywe, voorkom (Bouwman, 1985:35). Die aanduiding van gemeenskaplike sake as deel van die agenda van meerdere vergaderings is 'n erkenning van die noodsaak en eie, selfstandige plek van hierdie vergaderings in

kerkverband, te onderspeel. Op hierdie punt neig hulle dus om die delikate balans waarna vroeër verwys is, te verloor.

8 Vgl. Heidelbergse Kategismus, vraag en antwoord 55.

9 Daarom het die NGK in sy Kerkorde geen agendalysie vir die kerkraad nie, maar wel vir die ring, sinode en Algemene Sinode (NGK, 2003:14-18). 
die kerk. Al is die gemeente volledig kerk, is dit immers nie die hele kerk nie en kan kerkverband tog nie iets anders as kerk wees nie.

Besinning oor die bepaling van die opdragte van elke vergadering in die lig van hierdie beginsels, moet egter gereeld plaasvind om 'n skeeftrekking daarvan te verhoed. Dit is immers eie aan 'n gereformeerde kerk om altyd te reformeer.

'n Vraag in hierdie verband wat dikwels opduik, is die vraag na die gesag waarmee meerdere vergaderings hulle besluite neem. Interessante perspektiewe hierop kom uit die Doleansiekerkreg perspektiewe wat hulle uitgangspunt in die gemeente, as die kern van kerkwees, neem.

\section{Gesag van meerdere vergaderings}

Die kern van die argument oor die gesag van meerdere vergaderings lui dat die kerkraad oor die eintlike Christus- of kerklike gesag beskik en die meerdere vergaderings net oor afgeleide gesag, omdat die gemeente alleen volledig kerk is. Omdat kerkrade na meerdere vergaderings afvaardig en omdat hierdie vergaderings byeenkomste van gemeentes of kerke deur middel van hulle afgevaardigdes is, het ons hier slegs met die opgehoopte of kumulatiewe gesag van die gemeentes wat verteenwoordig is, te doen. Meerdere vergaderings handel hiervolgens dus met afgeleide gesag of met gesag wat hulle van die betrokke gemeentes kry. Met die beweging van die gemeente na die kerkverband, loop ook die gesag van die vergaderings van hierdie verband. Die aard van die gesag van meerdere vergaderings verskil nie van die aard van kerkraadsgesag nie. Dit is dieselfde gesag, hoewel dit van kerkraadsgesag afgelei is en die kumulatiewe aard daarvan dit in graad met kerkraadsgesag laat verskil. Op laasgenoemde punt word Voetius normaalweg bygetrek om die stelling te staaf dat die gesamentlike besluitneming van tien mense tog by iets beters moet uitkom as wanneer net een mens besluit (Bouwman, 1985:34-35; Jansen, 1952:144-145; De Gier, 1989:168-169; Strauss, 1997).

Die interessante spanning in hierdie standpunt is die bewering dat meerdere vergaderings, wat met minder gesag as kerkrade of met afgeleide teenoor eintlike gesag sou werk, vanweë die kumulatiewe aard daarvan tóg beter besluite as kerkrade behoort te neem. Nauta wys ook op die absurde konsekwensie dat 'n kerkraad wat iemand tot die Nagmaal toelaat, dit hiervolgens met die gesag van Christus doen. Die sinode wat oor die geloofsbelydenis en die Bybelvertaling besluit, doen dit egter sonder hierdie gesag wat van Christus 
verleen is. Sy gesag kom van die gemeentes af. Die kerkraad wat iemand van die Nagmaalstafel weerhou, kan dit op gesag van Christus doen, maar die klassis wat 'n predikant in oorleg met die partikuliere sinode afsit, kan nie (Nauta, 1971:124).

Die eintlike probleem met hierdie gesagstandpunt is dat dit by implikasie die gemeente tussen Christus en die meerdere vergadering inskuif. Dit is nie net Christus wat deur sy Woord en Gees op meerdere vergaderings regeer nie, maar by implikasie ook die gemeentes of kerkrade. Meerdere vergaderings word dus nie totaal en al Christokraties nie, maar óók kongregasionalisties regeer. Dit is immers van die gemeentes dat meerdere vergaderings hulle mandaat en opdrag kry.

Gereformeerd beskou, kan daar geen gesag, opdrag of mandaat in die kerk wees as dit nie van Christus kom nie. Christusgesag is egter ook Woordgesag, sonder enigiets anders wat moet bykom. As die gemeentes in opdrag van God onderling per kerkorde ooreenkom wat die take van meerdere vergaderings is, beteken dit nie dat hierdie vergaderings ook hulle gesag aan die gemeentes ontleen nie. Die enigste ware kerklike gesag waarmee hulle kan handel, is Christusgesag. Hulle werk dus, soos kerkrade, ook met 'n van-Christus-verleende gesag. Soos by die verkiesing en mandatering van kerkraadslede, moet daar hier ook 'n onderskeid tussen 'n kies- of plasingsreg en 'n gesagsreg gemaak word. Die reg om 'n persoon of 'n deputaatskap of 'n vergadering aan te wys om 'n taak vir Christus uit te voer, beteken nie om Christus as opdraggewer of eintlike gesagsdraer te vervang nie. 'n Kerkraad kan self ook nie met meer as net 'n van-Christus-verleende gesag werk nie. Kerkrade besit of beskik nie oor Christus se gesag nie. Indien 'n mens nie oor die gesag beskik nie, kan jy dit ook nie verleen of delegeer nie (uitgebreide beredenering by Strauss, 1997).

\section{Watter sake dien op die agendas van meerdere vergaderings?}

DKO-30 maak voorsiening vir twee soorte sake op die agendas van meerdere vergaderings: sake wat nie op mindere vergaderings afgehandel kan word nie en sake wat die kerke of gemeentes binne die betrokke meerdere vergadering in gemeen het.

Juis van die aanhangers wat 'n beweging suggereer vanaf die gemeentes na die kerkverband toe, kom 'n aandrang dat meerdere vergaderings slegs daardie sake mag hanteer wat vanaf mindere vergaderings, of hulle direk voorafgaande mindere vergadering, kom 
(De Gier, 1989:169-170). Om die selfstandigheid van die "kerke" binne die verband te handhaaf, moet die punte op die agenda van meerdere vergaderings ook deur hulle bepaal word.

Hierdie opvatting verteenwoordig 'n radikalisering van meerdere vergaderings as vergaderings van gemeentes deur middel van hulle afgevaardigdes en ontneem laasgenoemde hulle selfstandigheid. As 'n meerdere vergadering, met die lig tot sy beskikking, nalaat om sekere sake ter tafel te neem wat hom kan help om sy opdrag uit te voer, net omdat dit nie van 'n mindere vergadering af kom nie, raak hy 'n gevangene van die voorafgaande vergadering en versuim hy sy plig. Omdat hy met 'n van-Christus-verleende gesag werk, moet hy die lig wat van Christus af kom ten volle gebruik.

Op die vraag hoe sake van mindere vergaderings by meerdere vergaderings moet uitkom, word daar verskillende antwoorde gegee. Jansen (1952:145) stel die volgende voor: sake wat die mindere vergadering weens onmag nie kon afhandel nie en daarom verwys; wanbestuur by die mindere vergadering, wat die meerdere laat ingryp; en appèlle. Nauta (1971:132-133) opper die moontlikhede of 'n vraag, 'n instruksie, 'n beswaarskrif of appèlle van mindere na meerdere vergaderings kan gaan. Die Christian Reformed Church of North America maak in hierdie verband voorsiening vir appèlle, notas wat sekere sake of gedagtes onder die aandag van die meerdere vergadering bring (sonder dat hy aksie hoef te neem), 'n ouverture wat vra vir 'n formele besluit van die meerdere vergadering en gravamina (Engelhard \& Hofman, 2001:167-168). Veral die kwessies van instruksies, notas en ouvertures is te vaag om vas te stel of dit nie op mindere vergaderings afgehandel kan word nie. Op hierdie punt beweer Kruger (1966:180) tereg dat dit in stryd met DKO-30 is as ' $n$ mindere vergadering 'n saak na 'n meerdere vergadering verwys sonder om homself eers daaroor uit te spreek. Sentralisering van kerksake in meerdere vergaderings lyk dalk na kollegialisme en episkopalisme (Bouwman, 1985:35).

Ten opsigte van die sake wat die kerke, wat in 'n betrokke meerdere vergadering saamtrek in gemeen het, is Kruger (1966:190) ook reg as hy aanvoer dat dit beperkend verstaan moet word. Die bedoeling van die DKO-30 word dus gehonoreer. Hierdie beperkende benadering moet, met die opdrag van die betrokke vergadering, in die kerkorde versoen word, terwyl die kerkorde in die lig daarvan ook gereeld hersien moet word. Dan werk gereformeerde kerke reformatories. 


\section{Slot}

Die DKO-30 is 'n manier en verantwoorde maatreël om die selfstandigheid van die gemeente en dus die kerkraad te beskerm. Dit erken en beskerm ook die noodsaak en eie reg van die kerkverband en meerdere vergaderings. Tog skakel die DKO-30 nie die gereelde praktiese toepassing hiervan - wat voortdurend gepaard gaan met keuses - uit nie. Hierdie artikel alleen sal nie sorg vir die regte verhouding tussen kerkraad en meerdere vergaderings in ' $n$ bepaalde kerkverband nie. Dit moet gekoppel word aan 'n behoorlike kennis van die aard van 'n gereformeerde kerkverband.

\section{Geraadpleegde bronne}

BAVINCK, H 1967. Gereformeerde dogmatiek. Deel IV. (5e onveranderde druk.) Kampen: Kok.

BIESTERVELD, P. \& KUYPER, H.H. 1905. Kerkelijk handboekje. Kampen: Bos. BOS, F.L. 1950. De orde der kerk. Den Haag: Guido de Bres.

BOUWMAN, H. 1985. Gereformeerd kerkrecht. Deel II. (3e onveranderde druk.) Kampen: De Groot Goudriaan.

DE GIER, K. 1989. De Dordtse Kerkorde - een praktische verklaring. Houten: Den Hertog.

DU PLOOY, A. le R. 1979. Ekklésia en meerdere vergaderinge. Potchefstroom: $\mathrm{PU}$ vir $\mathrm{CHO}$. (Ongepubliseerde ThM-verhandeling.)

ENGELHARD, D.H. \& HOFMAN, L.J. 2001. Manual of Christian Reformed Church government. Grand Rapids: CRC.

ENGELSMA, D.J. 1996. The authority of major assemblies. Protestant Reformed Theological Journal, 30(1):38-59.

HARMANNIJ, K. 1990. Wegwijs in de kerkorde. Barneveld: De Vuurbaak.

HEYNS, J.A. 1977. Die kerk. Pretoria: NG Kerkboekhandel.

JANSEN, J. 1952. Korte verklaring van de Kerkorde der Gereformeerde Kerken. Kampen: Kok.

KRUGER, L.S. et al. 1966. Handleiding by die kerkorde van die Gereformeerde Kerk in Suid-Afrika. Potchefstroom: Pro Rege.

NAUTA, D. 1971. Verklaring van de kerkorde van de Gereformeerde Kerken in Nederland. Kampen: Kok.

NEDERDUITSE GEREFORMEERDE KERK. s.a. Die kerkorde. s.l: s.n.

NEDERDUITSE GEREFORMEERDE KERK. 2002. Handelinge van die Algemene Sinode. s.l.: s.n.

NEDERDUITSE GEREFORMEERDE KERK. 2003. Die kerkorde. Wellington: NGK Lux Verbi.BM.

kyk NEDERDUITSE GEREFORMEERDE KERK

PLOMP, J. 1971. De kerkorde van Emden (In Nauta, D. et al. De synode van Emden 1571-1971. Kampen: Kok. p. 4:88-121.)

PONT, A.D. 1981. Die historiese agtergronde van ons kerklike reg. Vol. I. Pretoria: HAUM.

PONT, A.D. 1991. Die historiese agtergronde van ons kerklike reg. Vol. II. Pretoria: Kital. 
PROTESTANTSE KERK IN NEDERLAND. s.a. Kerkorde en ordinanties. s.I: S.n.

RUTGERS, F.L. 1889. Acta van de Nederlandse synoden der zestiende eeuw. Utrecht: Kemink.

RUTGERS, F.L. 1971. De geldigheid van de oude kerkkenordening der Nederlandsche Gereformeerde Kerken. Amsterdam: Ton Bolland.

SADLER, T.H.N. 1991. Lidmaatskap: gebruike in die NG Kerk. (In Strauss, P.J., red. Byderwets en gereformeerd. Bloemfontein: NG Sendingpers. p. 6576.)

SPOELSTRA, B. 1989. Gereformeerde kerkreg en kerkregering. Hammanskraal: Teologiese Skool.

STRAUSS, P.J. 1997. Ecclesiastical assemblies possess, each according to its own character, an ecclesiastical authority entrusted to them by Christ. (In Neuser, W.H. \& Selderhuis, H.J., reds. Ordenlich und fruchtbar. Leiden: Groen. p. 79-98.)

STRAUSS, P.J. 1999. Die goedkeuring van kerkrade vir 'n nuwe verband in die NG kerkfamilie? Acta Theologica, 19(2):32-54.

STRAUSS, P.J. 2001. Kerkverband in die Nederduitse Gereformeerde Kerk vandag. Nederduitse Gereformeerde Teologiese Tydskrif, 42(3 \& 4):395405.

VAN DELLEN, I. \& MONSMA, M. 1967. The revised church order commentary. Grand Rapids: Zondervan.

VAN DEN HEUVEL, P. 1991. De Hervormde Kerkorde. Zoetermeer: Boekencentrum.

VAN DER LINDE, G.P.L. 1983. Die kerkorde. Pretoria: Van Wyk.

VAN 'T SPIJKER, W. 1971. Stromingen onder de reformatorisch gezinden te Emden. (In Nauta, D. et al. De synode van Emden 1571-1971. Kampen: Kok. p. 50-74.)

VAN WYK, B.J. 1981. Die Presbiterial-sinodale kerkbegrip. Pretoria: Kital.

VISSER, J. 1999. Die kerkorde in praktyk. Orkney: EFJS.

VOETIUS, G. s.a. Politica Ecclesiastica. Deel IV. s.I: s.n.

\section{Kernbegrippe:}

agendas van meerdere vergaderings

gemeenskaplike sake

kerkverband

mindere en meerdere vergaderings

onafgehandelde sake

\section{Key concepts:}

denomination

matters dealt with by major assemblies

matters not finished

matters which concern the churches in common

minor and major assemblies 
